\title{
Modified Soft Tissue Release Procedure in Idiopathic Congenital Talipes Equinovarus
}

\author{
Sharma $\mathrm{AK}^{1}$, Sharma $\mathrm{VP}^{2}$, Gupta $\mathrm{AK}^{3}$, Kumar $\mathrm{D}^{4}$ \\ ${ }^{1}$ Dr. Arvind Kumar Sharma, M.D. (P.M.R.), Resident, ${ }^{2}$ Prof. Vijai Prakash Sharma, M.S.(Ortho), D.N.B.(PMR), FICS, \\ FACS, FIMSA, MAMS, PG-Spine (Aust.), Professor, ${ }^{3}$ Dr. Anil Kumar Gupta, M.D., D.N.B.(P.M.R.), Associate \\ Professor \& Head , ${ }^{4}$ Dr. Dileep Kumar, M.S. (Ortho.), Assistant Professor. All are affiliated with Department of Physical \\ Medicine and Rehabilitation, King George's Medical University, Lucknow, Uttar Pradesh.
}

Address for Correspondence: Dr. Arvind Kumar Sharma, M.D. (P.M.R.), Resident, Department of Physical Medicine and Rehabilitation, King George's Medical University, Lucknow, Uttar Pradesh, India, e-mail: drarv25@gmail.com, Address 16/43- Shuklapur, Mohammadi (Kheeri) 262804.

\begin{abstract}
Introduction: Initial treatment of clubfoot is non operative usually, but cases which prove to be resistant require surgical treatment. The most commonly used posteromedial incisions have been reported to have complications like skin sloughing, dehiscence, infection, limitation of full correction, hypertrophic scar and recurrence. Thus the treatment is shifting towards less aggressive surgeries. The aim of the study is to evaluate the result of a "modified soft tissue release procedure" through a single posterior incision for the correction of the idiopathic clubfoot. Materials and Methods: We conducted a prospective therapeutic study reviewing patients with idiopathic congenital clubfoot resistant to conservative management in our institution between August 2013 and July 2014. Surgical management was given by modified soft tissue release procedure. Pre and post treatment clinical, podogrammical, and radiological assessments were done. Results: A total of 82 clubfeet were reviewed. Surgical correction observed in the feet was clinically significant as per Pirani scoring, foot bimalleolar angle and talocalcaneal angle lateral view and talocalcaneal index. Improvement was clinically not significant as per talocalcaneal angle in anteroposterior view. Complications included postoperative pyrexia, pain and stiffness, superficial wound infection, 1 foot with treatment failure and 2 feet with residual deformity in the follow up period. Final clinical outcome revealed excellent and good result in $85.36 \%$ cases by this technique. Conclusion: The present study concludes that the procedure is effective in treating the deformity. The results are equivalent while complications are lesser compared to more aggressive surgeries.
\end{abstract}

Keywords: Talipes equinovarus, Pirani scoring, Podogrammical assessment, Foot bimalleolar angle.

\section{Introduction}

The term 'talipes' is derived from 'talus' (Latin = ankle bone) and 'pes' (Latin = foot). Nicholas Andry (1743) in "Orthopaedica" called the deformity as "Pedes Equinal i.e. resembling the foot of the horse. Idiopathic congenital talipes equinovarus is a complex three dimensional deformity with an incidence between 0.64 and 6.8 per 1000 live births, varying with race and geography $[1,2]$. It is one of the most common congenital foot anomalies and was first described by Hippocrates in the year 400 BC [3]. It still continues to challenge the skills of the surgeon, irrespective of whether the foot is treated by conservative or operative

Manuscript received: $1^{\text {st }}$ June 2015

Reviewed: $4^{\text {th }}$ June 2015

Author Corrected: $24^{\text {th }}$ June 2015

Accepted for Publication: $7^{\text {th }}$ July 2015 means.

During the second half of the $20^{\text {th }}$ century, the primary treatment of idiopathic clubfoot has ranged from gentle manipulations to aggressive surgical treatment. Surgical management predominated because it was considered as a method that could obtain full and lasting correction. Based on long-term follow up studies it is realized that the results of surgical interventions are unpredictable $[4,5,6]$. Extensive soft-tissue releases can result in complications like skin sloughing, dehiscence, infection, and limitation of full correction at the time of surgery, delayed wound healing, gaping, stiffness, joint arthrosis, and late osteoarthritis. In 3-30\% of cases, it leads to hypertrophic scar and recurrence of the deformity $[7,8,9,10]$. Such observations along with the 
good results of the Ponseti method [11,12] shifted treatment of clubfoot towards a more conservative approach consisting of manipulations and serial casting, and minimal invasive surgery. Open surgery is usually reserved for more severe cases that failed serial casting. However, even in these cases, current surgical procedures are less aggressive than procedures performed three decades ago [13].

Considering this we have used a "modified soft tissue release procedure" through a single posterior incision for the correction of the idiopathic clubfoot to avoid the above mentioned complications.

In this technique a vertical incision is given from the lowest attachment of the Achillis tendon in the calcaneum to its musculotendinous junction, coursing parallel to the tendon on its medial side, sparing the medial curved part of Turco's incision, thus reducing the chances of gaping or infection. We used only posterior incision unlike Turco's incision in which it was extended medially which at times may undergo marginal flap necrosis. However this technique is not without complications. Minor complications like wound infection, postoperative pyrexia, pain and stiffness and residual deformity were observed, highlighting the need for larger studies.

\section{Materials and Methods}

A therapeutic prospective observational study was done in the Department of Physical Medicine and Rehabilitation, K.G.M.U. between August 2013 and July 2014 on all idiopathic congenital talipes equinovarus patients who were resistant to conservative line of management. It included cases in whom there was failure to attain correction after a trial of non operative treatment and in whom there was failure to maintain correction with recurrent deformity. Patients above 4 years of age or those with rigid joint and bony deformity were excluded from the study. Those not willing for surgery, unfit for surgery or lost to follow up were also excluded.

Modified soft tissue release was done. A vertical incision was given from the lowest attachment of tendo Achillis in the calcaneum to its musculotendinous junction, coursing parallel to tendon on its medial side. A medial extension of the incision was avoided. Sheath of the tendon was divided vertically and the tendon was cleared in its entire length. Z-plasty lengthening of tendo Achillis was done in A-P plane. With a knife the tendo Achillis was divided longitudinally into lateral and medial halves for a distance of $2.5-4 \mathrm{~cm}$. The distal end of the medial half was detached from the calcaneus to prevent recurrence of varus deformity of the heel, the lateral half was divided proximally. The fibrous areolar tissues were cleared and the tight fibrous sheath was slit, exposing the posterior portion of capsule of ankle and subtalar joints. The posterior aspect of capsule of tibiotalar and talocalcaneal joint was exposed by retracting the neurovascular bundle and flexor hallucis longus tendon anteriorly. The posterior capsule of tibiotalar joint was divided by a horizontal incision. If necessary, posterior talofibular ligament was also divided (it holds the talus in a plantar flexed position). Next the posterior capsule of the subtalar joint was divided. Z- plasty lengthening of tibialis posterior, and flexor hallucis longus was done. The tendo Achillis was resutured with proper tension with ankle in neutral position. A sterile bulky dressing followed by above knee well padded groin to toe POP cast with knee in 70-90 degree flexion and ankle dorsiflexed only to neutral position to prevent the tension on skin edges was applied.

2 weeks after surgery cast was removed and stitches were cut. The foot was brought into further dorsiflexion (not more than 20 degree) and a new well moulded above knee cast was applied in corrected position for further 2 weeks. After removal of this cast the foot and ankle were held in slightly overcorrected position in a night splint, at least 23 hours per day for the next 3 months or till the child was cruising. After this the night splint was used only for nightwear and CTEV shoes were given for daytime use to facilitate walking. To maintain correction it was used until skeletal growth remodels and straightens the medial and plantar tilting of the head and neck of talus, and normal articular relationship was restored. Along with this corrective exercises were taught.

The patients were followed monthly for 3 months and then every 3rd month for 1 year. Results of surgical correction were assessed on clinical, radiological and podogrammical findings at regular intervals.

Clinical assessment for the severity of the deformity (Flynn et al) was done using the Pirani scoring system $[14,15]$ based on six clinical signs. Podogrammical evaluation was done by taking foot bimalleolar angle as described by McKay [16, 17]. This is the angle formed by the bimalleolar plane and the axis of foot, foot being kept in a weight bearing position and foot print taken on a plain white paper. 


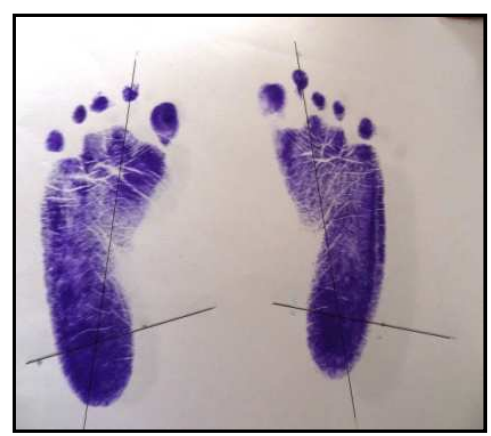

Figure 1: Foot bimalleolar angle measurement.

On radiological assessment Talo-calcaneal angle was observed in X-ray film in stress dorsiflexion of foot. In AP view, angle is measured between long axis of talus and long axis of calcaneum parallel to its lateral border. Normal angle is 2040 degree. In lateral view, angle is taken between long axis of talus and the plantar surface of calcaneum. Normal value is 35-55 degree. Talocalcaneal index is the sum of these two. It is $>40$ degree in clubfoot.

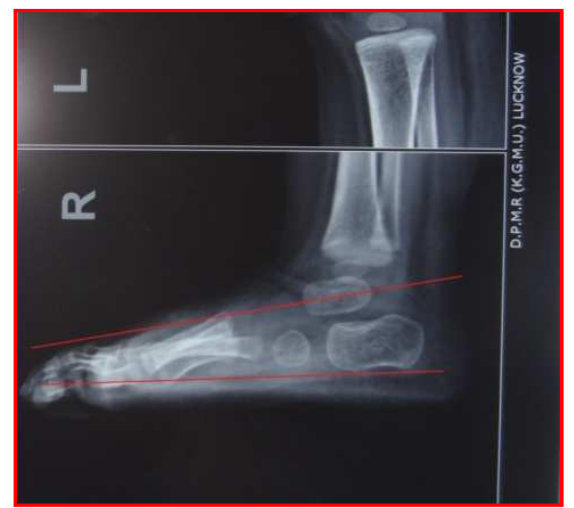

Figure 2: X-ray AP view

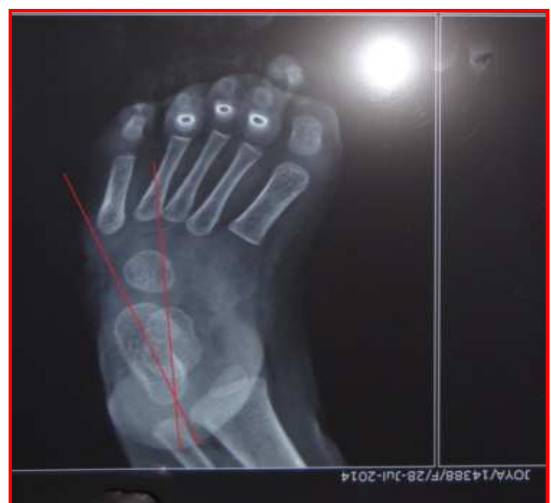

Figure 3: X-ray Lateral view

\section{Results}

A total of 50 patients with 82 clubfeet were reviewed. Mean age was $13.84 \pm 10.41$ months. There were $34(68 \%)$ males and $16(32 \%)$ females. $64 \%$ of the parents were illiterate or had undergone only primary schooling. Rest $34 \%$ had high school and above education. $40 \%$ children presented at the age above 12 months of the age while $40 \%$ presented below 6 months of age and $20 \%$ were of 6-12 months. Those who presented late were primarily children of illiterate parents. 32 children (64\%) had bilateral foot involvement while 18 children $(36 \%)$ had unilateral involvement. Among 18 unilateral cases right limb was affected in 10 cases, accounting for 55\% and left limb was affected in 8 cases, accounting for $45 \%$. $17(34 \%)$ were first born children. Family history was positive in 6 cases (12\%). History of consanguinity was given in 4 cases $(8 \%)$.

Pre-treatment $80.48 \%$ feet were moderately deformed (based on Pirani Scoring as per Flynn et al; Pirani 2.5-5.0) and $19.52 \%$ were of severe deformity (Pirani >5). Post treatment $97.56 \%$ feet improved to mild category (Pirani <2.5) and $2.44 \%$ to moderate category. None of the feet remained severely deformed. The mean Pirani score changed from $4.85 \pm 0.49$ to $1.09 \pm 0.50$ ( $\mathrm{p}=0.0001$ ). The minimum pre-treatment pirani score was 4 while the maximum was 5.5 . Posttreatment it changed to 0.5 and 3.0 respectively.

Table 1: Age wise distribution of Pirani scores

\begin{tabular}{|c|c|c|c|c|}
\hline Age distribution & $\begin{array}{l}\text { Mean initial Pirani } \\
\text { score }\end{array}$ & $\begin{array}{l}\text { Mean final Pirani } \\
\text { Score }\end{array}$ & Mean difference & $P$ value \\
\hline$<6$ months & $4.78 \pm 0.34$ & $0.9 \pm 0.03$ & 3.88 & 0.0001 \\
\hline months $6-12$ & $4.81 \pm 0.47$ & $1.0 \pm 0.01$ & 3.81 & 0.0001 \\
\hline$>12$ months & $5.176 \pm 0.78$ & $1.32 \pm 0.001$ & 3.85 & 0.0001 \\
\hline
\end{tabular}


Age wise assessment of initial and final Pirani Scoring also revealed significant improvement in all age groups. The mean difference in correction was higher among $<6$ month age group.

Table 2: Distribution of Pirani scores among all enrolled feet

\begin{tabular}{|l|l|l|}
\hline Pirani Score & Pre-op cases (\%) & Post-op cases (\%) \\
\hline 0.5 & 0 & $14(17.07 \%)$ \\
\hline 1.0 & 0 & $52(63.41 \%)$ \\
\hline 1.5 & 0 & $6(7.32 \%)$ \\
\hline 2.0 & 0 & $8(9.76 \%)$ \\
\hline 2.5 & 0 & 0 \\
\hline 3.0 & 0 & $2(2.44 \%)$ \\
\hline 3.5 & 0 & 0 \\
\hline 4.0 & $8(9.76 \%)$ & 0 \\
\hline 4.5 & $18(21.95 \%)$ & 0 \\
\hline 5.0 & $40(48.78 \%)$ & 0 \\
\hline 5.5 & $16(19.51 \%)$ & 0 \\
\hline
\end{tabular}

\section{Podogrammical assessment;}

As per podogrammical assessment, $85.36 \%$ feet showed improvement from group 3 (FBM angle $<66.6^{0}$ ) to group 1 (FBM angle $>73.2^{0}$ ) and $12.2 \%$ improved to group 2 (FBM angle $66.6^{0}-73.2^{\circ}$ ). Mean FBM angle improved from $62.07^{0} \pm 2.53^{0}$ to $77.19^{0} \pm 3.99^{0}(\mathrm{p}=0.0001)$. Evaluation revealed significant improvement $(\mathrm{p}=0.0001)$ in all age groups as shown in table.

Table 3: Age wise distribution of FBA

\begin{tabular}{|c|c|c|c|c|}
\hline Age group & $\begin{array}{l}\text { Mean } \\
\text { initial FBA }\end{array}$ & $\begin{array}{ll} & \text { Mean final } \\
\text { FBA } & \end{array}$ & $\begin{array}{l}\text { Mean } \\
\text { difference }\end{array}$ & p- value \\
\hline$<6$ months & $64.06 \pm 3.23$ & $79.44 \pm 3.67$ & 15.38 & 0.0001 \\
\hline months ${ }^{6-12}$ & $63.75 \pm 2.45$ & $78.5 \pm 3.24$ & 14.75 & 0.0001 \\
\hline$>12$ months & $59.76 \pm 2.36$ & $74.47 \pm 3.56$ & 14.71 & 0.0001 \\
\hline
\end{tabular}

Similar to clinical assessment, age wise evaluation of FBM angle also revealed significant improvement in all age groups. However, the mean difference in correction was higher among <6 month age group.

As per radiological findings, mean talocalcaneal angle AP view improved from $14.02^{0} \pm 1.36^{0}$ to $15.90^{\circ} \pm 2.80^{\circ}$ ( $\mathrm{p}=0.09$ ) Mean talocalcaneal angle lateral view improved from $19.95^{0} \pm 1.11^{0}$ to $29.21^{0} \pm 3.64^{0}$ ( $\mathrm{p}=0.0001$ ). Finally talocalcaneal index increased from $33.97^{0} \pm 1.96^{0}$ to $45.12^{0} \pm 5.65^{0}(\mathrm{p}=0.0001)$.

No procedure can be without its complications, may it be major or minor. In our technique minor complications like post operative pyrexia $(12.20 \%)$, superficial wound infection $(9.76 \%)$, and pain and stiffness $(4.88 \%)$ were noted mainly. In major complications, post operative residual deformity was noticed in $2.44 \%$ cases and failure of correction was seen in $1.22 \%$ cases. Apart from this, there were no cases with injury to neurovascular bundle, tourniquet skin blisters, deep wound infection or wound dehiscence.

Pirani scoring revealed excellent (Pirani $\leq 0.5$ ) result in $17.07 \%$ cases and good result (Pirani $\leq 1.5)$ in $68.29 \%$ cases. Fair result (Pirani $\leq 2.5$ ) was observed in $12.19 \%$ cases. Poor result (Pirani $>2.5$ ) was noticed in $2.43 \%$ cases. 


\section{Discussion}

The anatomy and kinesiology of the tarsus of the normal and of the clubfoot is complex. The deformity has four components [18] - equinus at the ankle, varus at the ankle and subtalar joint, adduction of the forefoot and cavus. In addition, there is an element of tibial torsion, which contributes to the deformity. The most severe deformities occur in the hind part of the foot. Talus and calcaneus is usually in severe equinus, the calcaneus is in varus angulation and medially rotated and the navicular is severely displaced medially. Pathological changes are more marked in patients who have walked as opposed to infants who have never walked [1]. Farabeuf [16,17,19] considered the displacement of the tarsal bones in a child's clubfoot to be the most extreme position caused by the excessive pull of the tibialis posterior abetted by the gastrosoleus, tibialis anterior, long toe flexors and plantar muscles. Similarly the ligaments and posterior capsule of the ankle are constricted which restrict even the normal dorsiflexion. The tendo Achillis is contracted and this undoubtedly is a major obstacle to ankle dorsiflexion in clubfoot. Contracture of the tendo Achillis also prevents inferior migration of the posteromedial tubercle of the calcaneum, preventing eversion of foot.

The aim of treatment of clubfoot is to get the foot dorsiflexed and everted well beyond neutral. In the treatment of clubfoot, nonsurgical treatment should be attempted initially, and this can be successful [20,21,22]. The two methods most commonly used being the Ponseti technique and the Kite and Lovell technique. However despite the best efforts, some clubfeet cannot be completely corrected with non operative treatment. In such feet, soft-tissue release is clearly indicated [23]. At present there is no universally accepted criterion for the use of the various surgical techniques. Owing to the multitude of problems that are occurring with the two most common surgical incisions; Turco's posteromedial type of incision and the circumferential Cincinnati incision, the objective of clubfoot treatment should generally be successful correction through minimal surgical release, if possible, by single operation $[13,23]$. The study evaluated the results of surgical correction in 'idiopathic C.T.E.V.' by "modified soft tissue release procedure".

As per the findings, postoperatively the Pirani scores reduced to lower values. That is almost all feet became more flexible than earlier. Paired $t$ - test revealed significant decrease in the Pirani score $(p=0.0001)$ in all the age groups at the final follow up suggesting significant improvement in the deformity with our technique in all age groups.

On comparison of radiological and podogrammical assessment, paired $t-$ test revealed significant improvement in foot bimalleolar angle, talocalcaneal angle lateral view and talocalcaneal index. Only talocalcaneal angle anteroposterior view showed non significant improvement.

The analysis of results obtained with clinical and podogrammical assessment (which is an easier procedure to perform than X-ray) suggests that the results obtained with the two are similar, be it applied to any age group of participant.

Wound complications are significant in India due to its subtropical location with hot and humid climate leading to increased chances of skin and soft tissue infection. Characteristics of these complications can be associated with the surgical approach used [24]. Wound complications following posteromedial release are inherent to the technique only as the contracted skin posteromedially will never suffice as a cover once the foot is brought to the neutral position. Skin necrosis rate as described by Turco [25] in 1971 was 6\%, and Aggarwal et al. [26] was 3\%. However, we found no cases with skin necrosis in our study.

Major complication with our technique was noted in 3 feet. In 2 residual deformity was observed. The residual deformity occurred in cases where the age of children were 36 months and 30 months and the children were walking on deformed foot since the age of 12 months each. This might have made the tissue less resilient and more resistant to correction. In 1 foot (1.22\%) there was failure of the procedure due to non compliance of the patient with exercise programmes and usage of corrective brace. Others were minor complications like postoperative pyrexia, superficial wound infection, pain and stiffness.

The overall result of our technique can be assessed with respect to other surgical incisions. Our study revealed $87.8 \%$ excellent and good results, $9.76 \%$ fair and $2.44 \%$ poor results. Turco [5] carried extensive posterior, medial, plantar and subtalar releases through posteromedial incision but primarily fixed the talocalcaneal and talonavicular joints with kirschner wires. He had excellent and good results in $86 \%$ of cases and $9 \%$ fair results and failure in $5 \%$ of cases. Derosa G.P. et al. [27], carried out one stage 
posteromedial release in resistant clubfoot and reported excellent and good results in $80 \%$ of cases, fair in $13 \%$ and failure in $7 \%$ of cases. Varma et al. [28] carried out modified posteromedial release using twin incisions and reported excellent results in $7.89 \%$, good in $72.36 \%$ and fair results in $15.79 \%$ with failure in $3.94 \%$.

The strength of the study was prospective consecutive enrollment of subjects, a uniform treatment protocol and careful follow up. A key limitation of this study was a small sample size and short follow up period. Further study with larger number of subjects and longer follow up obtaining well validated results is highly desirable.

\section{Conclusion}

The present study highlights that the difference between means of initial and final pirani scores shows significant correction $(\mathrm{p}=0.0001 \quad$ signifying modified posteromedial soft tissue release procedure with only posterior incision to be effective in treating the deformity. The Pirani scoring system was found reliable, practicable, reproducible, quick, and easy to use. The FBM angle is the simple method of assessment that can be used to comment on the severity of clubfoot and its response to treatment.

Excellent and good results were obtained in majority of patients. A single stage modified posteromedial soft tissue release through posterior incision gives consistent satisfactory results in the operative correction of moderate to severe idiopathic clubfoot achieving nearly full correction of the feet.

\section{Funding: Nil}

Conflict of interest: Nil

Permission from Institutional Research Board (IRB): Yes

\section{References}

1. Ikeda $\mathrm{K}$. Conservative treatment of idiopathic clubfoot. J Pediatr Orthop. 1992 Mar-Apr;12(2):217-23.

2. Barker S, Chesney D, Miedzybrodzka Z, Maffulli N. Genetics and epidemiology of idiopathic congenital talipes equinovarus. J Pediatr Orthop 2003; 23(2): 265272.

3. Kite JH. Non operative treatment of congenital clubfeet. Clin Orthop Relat Res. 1972;84:29-38
4. Ippolito E, Farsetti P, Caterini R, Tudisco C. Long term comparative results in patients with congenital clubfoot treated with two different protocols. J Bone Joint Surg Am 2003; 85-A(7): 1286-1294

5. Hutchins PM, Foster BK, Paterson DC, Cole EA. Long-term results of early surgical release in club feet. J Bone Joint Surg Br 1985; 67(5): 791-79.

6. Dobbs MB, Nunley R, Schoenecker PL. Long-term followup of patients with clubfeet treated with extensive softtissue release. J Bone Joint Surg Am 2006; 88(5): 986-996 [PMID: 16651573 DOI: 10.2106/JBJS.E.00114].

7. Carroll NC, McMurtry R, Leete SF. The pathoanatomy of congenital clubfoot. Orthop Clin North Am 1978;9(1):225-32.

8. Carroll NC. Congenital clubfoot: Pathanatomy and treatment. Instr Course Lect. 1988;37:93-106.11.

9. Crawford AH, Gupta AK. Clubfoot controversies: Complications and causes for failure. Instr Course Lect 1996;45:339-46.

10. Hutchins PM, Foster BK, Paterson DC, Cole EA. Long-term results of early surgical release in club feet. J Bone Joint Surg Br 1985;67(5):791-9.

11. Laaveg SJ, Ponseti IV. Long-term results of treatment of congenital club foot. J Bone Joint Surg Am 1980; 62(1): 23-31.

12. Cooper DM, Dietz FR. Treatment of idiopathic clubfoot.A thirty-year follow-up note. J Bone Joint Surg Am 1995; 77(10):1477-1489.

13. Marios G Lykissas et al.(2013) Ponseti method compared with soft-tissue release for the management of clubfoot: A meta-analysis study.World Journal of Orthopaedics 2013 July 18;4(3):144-153.

14. Dyer PF, Davis N. The role of the Pirani scoring system in the management of club foot by the Ponseti method. J Bone Joint Surg Br 2006 ; 88-B(8);10821084.

15. Pirani S, Outerbridge HK, Sawatzky B, Stothers K. A reliable method of clinically evaluating a virgin clubfoot evaluation.21 SICOT Congress. 
16. Mckay DW. New concept of and approach to clubfoot treatment. Section 01; Principles and morbid anatomy.J Pediatr Ortop 1982;2:347-356.

17. Mckay DW. New concept of and approach to clubfoot treatment. Section 02; Principles and morbid anatomy.J Pediatr Ortop 1983;(3):10-21.

\section{Kite JH. Non operative treatment of congenital} clubfoot. Clin Orthop 1970; 84:29-38.

19. Malcom swann, Llyod Roberts, Caterall A. Anatomy of uncorrected clubfoot. J Bone Joint Surg1969;51-B,263.

20. Coleman, S.S.: Complex Foot Deformities in Children. Philadelphia,Lea \&Febiger, 1983, pp. 23-110.

21. Lovell, W.W., and Winter, R.B.: Pediatric Orthopaedics, Vol. 2.Philadelphia,J.B. Lippincott, 1978, pp. 917-930.

22. Tachdjian, M.O.: Pediatric Orthopaedics, Vol. 1. Philadelphia,W.B. Saunders, 1972, pp. 1274-1322.
23. R. Jay Cummings, Richard S. Davidson, Peter F. Armstrong, Wallace B. Lehman, Congenital Clubfoot J Bone Joint Surg Am, 2002 Feb;84-A(2):290-308.

24. Singh BI, Vaishnavi AJ. Modified Turco procedure for treatment of idiopathic clubfoot. Clin Orthop Relat Res 2005;438:209-14.

25. Turco VJ. Surgical correction of the resistant club foot. One-stage posteromedial release with internal fixation: a preliminary report. J Bone Joint Surg Am, 1971;53(3): 477-97.

26. Aggarwal ND, Singh HS, Mittal RL. Evaluation of tibialis posterior transfer on surgical treatment of congenital clubfoot. IJS1967;29:4-105.

27. Main J B.,Crider R.J.,Polk M.,Lloyg-Roberts, et al :The resuts of early operation in TEV,Journal of Bone and Joint Surgery.1977; 59-B, 337-341.

28. Varma H S , Agarwal AC et al. Surgical management of congenital idiopathic club foot by twin incisions.J Orthop Allied Sci 2013;1:18-21

\section{How to cite this article?}

Sharma AK, Sharma VP, Gupta AK, Kumar D. Modified Soft Tissue Release Procedure in Idiopathic Congenital Talipes Equinovarus. Int J Med Res Rev 2015;3(6):572-578. doi: 10.17511/ijmrr.2015.i6.108. 